\title{
KATEGORISASI JENIS INTERAKSI PEMERINTAH DAN MASYARAKAT SERTA POPULARITAS MEDIA SOSIAL PEMERINTAH DAERAH
}

\author{
Afifah Nurul Izzati, Azmi Pratama, IGAA Mas Aristamy, Nina Fadilah Najwa dan Nur Aini \\ Rakhmawati
}

Information System Department, Faculty of Information Technology and Communication, Institut Teknologi Sepuluh Nopember (ITS), Jl. Arief Rahman Hakim, Surabaya, 60111, Indonesia

E-mail: fifah.afifah26@gmail.com,azmi16@mhs.is.its.ac.id, aristamy16@mhs.is.its.ac.id, nina.fadilah.najwa16@mhs.is.its.ac.id,nur.aini@is.its.ac.id

\begin{abstract}
The success of policies and programs proposed by governments depends on effective communication factors. Social media application is one of alternative media of communication between government and citizen. Social media can provide two-way interaction between citizen and government. The government currently has a mission of using social media, namely interactions are one way push, two way pull and Network co-design of service. This study aims to analyze the type of interaction and characterize the popularity of government social media, in this case a fanpage facebook local government. The results of this study indicate that the popularity of local government fanpage facebook is low with the evidence is $79 \%$ classified as unpopular. This is also related to the type of interaction that occurs on government social media, evidenced by the still low participation and collaboration between the community and the government.
\end{abstract}

Keywords: Facebook, Interaction Type, Government, Popularity

\begin{abstract}
Abstrak
Keberhasilan kebijakan dan program yang di usulkan oleh pemerintah bergantung pada faktor komunikasi yang efektif. Aplikasi media sosial merupakan salah satu alternatif media komunikasi antara pemerintah dan masyarakat. Media sosial dapat menyediakan interaksi dua arah antara masyarakat dan pemerintah. Pemerintah saat ini mempunyai misi dalam penggunaan media sosial, yaitu,melakukan interaksi one way push, two way pull dan Network co-design of service. Penelitian ini bertujuan untuk menganalisa jenis interaksi tersebut dan menentukkan popularitas dari media sosial pemerintah, dalam hal ini berupa fanpage facebook pemerintah daerah. Hasil dari penelitian ini menunjukkan bahwa tingkat popularitas dari fanpage facebook pemerintah daerah tergolong rendah, yaitu,sebanyak $79 \%$ tergolong tidak populer. Hal ini juga berkaitan dengan jenis interaksi yang terjadi, dibuktikan dengan masih rendahnya partisipasi dan kolaborasi antara masyarakat dengan pemerintah.
\end{abstract}

Kata Kunci: Facebook, Jenis Interaksi, Pemerintah, Popularitas

\section{Pendahuluan}

Komunikasi menjadi salah satu faktor yang tidak dapat diabaikan oleh manusia, karena pada dasarnya komunikasi adalah esensi kehidupan manusia sebagai makhluk sosial. Komunikasi dapat didefinisikan sebagai tindakan mentransmisikan dan menerima informasi. Komunikasi juga menjadi faktor yang sangat berperan dalam keberhasilan sebuah organisasi, karena hanya melalui komunikasi, pemimpin dalam organisasi dapat merencanakan, mengatur dan memimpin orang-orang yang ada di dalam organisasi tersebut. Hal ini menyiratkan bahwa keterampilan komunikasi setiap orang mempengaruhi keefektifan pribadi dan organisasi, tidak terkecuali padaorganisasi milik pemerintah[1].
Keberhasilan kebijakan dan program yang di usulkan oleh pemerintah bergantung pada faktor komunikasi yang efektif. Komunikasi yang berhasil, tidak hanya pemerintah yang mengambil peran dalam berkomunikasi atau menyampaikan informasi kepada masyarakat, namun juga bagaimana masyarakat dan pemerintah dapat saling berinteraksi satu sama lain, khususnya bagaimana masyarakat dapat memanfaatkan komunikasi sebagai cara dalam menyampaikan aspirasi, saran atau kritik [2].Tujuan utama komunikasi yang dilakukan oleh pemerintah adalah untuk membuat tindakan pemerintah lebih transparan dan menghasilkan interaksi eksternal, atau dapat dikatakan dengan respon [3]. Pada tahap inilah interaksi dari masyarakat memiliki peran penting dan sangat dibutuhkan untuk ke- 
- Intensif $\quad$ Tidak Intensif

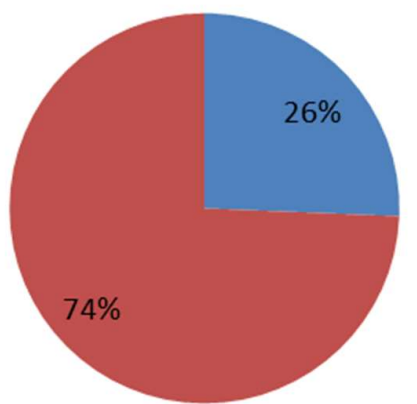

Gambar 1. Jenis Interaksi Two Way Pull berdasarkan Like per postingan

berhasilan kebijakan dan program dari pemerintah, karena berhasilnya program dan kebijakan pemerintah dapat diukur melalui respon masyarakat. Jika masyarakat merespon dengan positif, maka pemerintah dikatakan berhasil, namun jika respon masyarakat negatif, maka pemerintah masih perlu untuk memperbaiki program atau kebijakan tersebut [2].

Aplikasi media sosial salah satu alternatif media komunikasi antara pemerintah dan masyarakat. Media sosial pemerintah daerah dapat diakses secara luas dan penggunanya dapat saling berinteraksi termasuk masyarakat dan pemerintahan. Masyarakat dapat memberikan komentar, melakukan postingan, mengirim pesan, menggunakan kembali informasi yang dibagikan pada fanpages milik pemerintah. Aplikasi media sosial yang digunakan untuk internal dan eksternal adalah untuk memenuhi komunikasi dengan masyarakat yang tidak menggunakan cara yang tradisional dalam berinteraksi dengan pemerintah. Media sosial dapat menyediakan interaksi dua arah antara masyarakat sebagai pengelola informasi yang disebarkan dan mampu berinteraksi atau menjawab feedback yang diberikan oleh masyarakat [4].

Feedback yang diberikanpun bermacam-macam bentuknya. Dari feedback yang diberikan tersebut,ada yang mendukung berdasarkan alasan mereka sendiri, ada yang berbeda pendapat, ada yang menguatkan atau membantah pendapat dari masyarakat lain, ada yang memberikan feedback dengan penuh kesopanan dan ada yang berpendapat dengan sangat jelas. Beragamnya bentuk feedback yang diberikan tidak lepas dari berbagai faktor diantaranya adalah jenis kelamin, usia, dan tingkat pendidikan[5].

Jenis interaksi berdasarkan penggolongan yang dilakukan oleh [4], terdapat tiga tipe taktikal interaksi berdasarkan misi dan tujuan dari pembuatan media sosial bagi pemerintah. Pertama, misi transparansi untuk menyebarkan informasi yang
Intensif $\quad$ Tidak Intensif

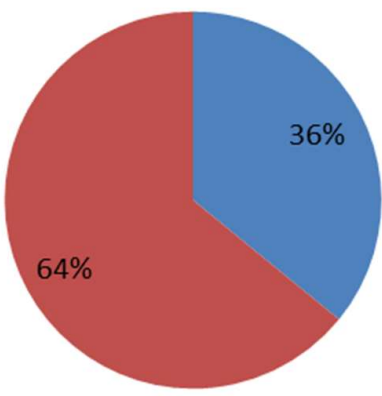

Gambar 2. Jenis Interaksi Two Way Pull berdasarkan Komentar per postingan

mengedukasi dilakukan dengan interaksi satu arah yang dilakukan oleh pemerintah, sehingga akan membentuk kepercayaan masyarakat. Kedua, misi partisipasi untuk dapat adanya keterikatan antara masyarakat dan pemerintah melalui interaksi dua arah sehingga hasil yang dicapai berupa konsultasi, keluhan, maupun kepuasan. Ketiga, misi kolaborasi untuk membangun aksi dua arah dengan interaksi jaringan yang akan menghasilkan komunitas, pembangunan isu-isu serta masyarakat yang memiliki peran aktif.

Berdasarkan paparan di atas, maka perlu dilakukan kategorisasi jenis interaksi dan melihat popularitas media sosial pemerintah, yang ditujukan untuk pemerintah dan masyarakat. Adapun manfaat yang akan diperoleh dari mengkategorisasi dan melihat popularitas ini adalah mengetahui keterkaitan antara misi, tujuan, dan jenis interaksi yang digunakan berdasarkan akusisi data fanpage facebook pemerintah daerah dalam rentang waktu selama dua bulan dan 10 hari. Akuisi data yang dilakukan untuk melihat interaksi antara pemerintah dan masyarakat adalah dari jumlah postingan, jumlah komentar, jumlah like dan share postingan. Sedangkan untuk melihat popularitas media sosial pemerintah dilakukan akusisi data pengikut dan likes fanpage facebook.

\section{Penelitian Terkait}

Pada penelitian yang dilakukan oleh Sara Hofmann et al [2] mengenai pemanfaatan penggunaan media sosial oleh pemerintah daerah di Jerman yang bertujuan untuk mengelola komunikasi eksternal dengan masyarakat sudah mulai digunakan. Penggunaan media sosial bertujuan untuk mengatasi kekurangan dari komunikasi tradisional atau offline yang dilakukan oleh pemerintah sebelumnya. Dalam mengukur keberhasilan komunikasi melalui penggunaan media sosial yang dilakukan oleh pemerintah, penelitian ini mengacu pada frekuensi 
Intensif $\quad$ Tidak Intensif

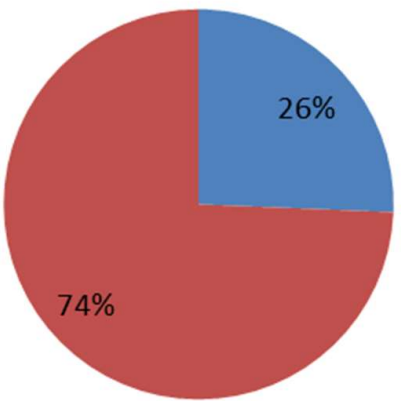

Gambar 3. Jenis Interaksi Two Way Pull berdasarkan Like per postingan

dan polaritas komentar masyarakat terhadap postingan pemerintah. Ditemukan pada penelitian ini bahwa fitur multimedia seperti foto dan video berkontribusi terhadap keberhasilan komunikasi.

Penggunaan media sosial oleh pemerintah memiliki potensi tidak hanya untuk memperbaiki penyediaan informasi dan layanan, namun juga memungkinkan sebagai bentuk baru dari interaksi pengguna ke pengguna yang dapat mendorong pertukaran opini publik sehingga dapat mendorong kewarganegaraan yang positif. Adanya penggunaan media sosial oleh pemerintah berpotensi dalam membentuk ruang publik yang memfasilitasi interaksi deliberatif [5].

Penggunaan media sosial menawarkan kepada pemerintah untukmeningkatkan transparansi dana akuntabilitas, dengan melibatkan semakin banyak warga untuk berpartisipasi dan berkolaborasi dalam pengambilan keputusan untuk memperbaiki manajemen informasi dan akses layanan publik. Menurut penelitian ini, penggunaan media sosial menguntungkan bagi pengguna karena dapat meningkatkan interaksi langsung antara masyarakat dengan pemerintah. Pengguna yang dimaksud adalah masyarakat dan pemerintah yang menggunakan media sosial. Bagimasyarakat, media sosial mendukung mereka untuk berinteraksi dengan pemerintah, karena mereka memiliki kesempatan memberikan sudut pandang mereka sendiri atasi informasi yang diberikan oleh pemerintah daerah. Sedangkan bagi pemerintah, media sosial dapat mempercepat penyebaran informasi dan mempermudah mendapatkan umpan balik atau tanggapan dari masyarakat[6].

Penggunaan aplikasi media sosial telah meluas hingga ke sektor publik dan digunakan bertujuan untuk meningkatkan transparansi, partisipasi, dan kolaborasi pemerintah federal Amerika Serikat. Banyak instansi pemerintah melakukan percobaan terhadap penggunaan media sosial, namun sangat sedikit yang secara aktif mengukur dampak
Intensif Tidak Intensif

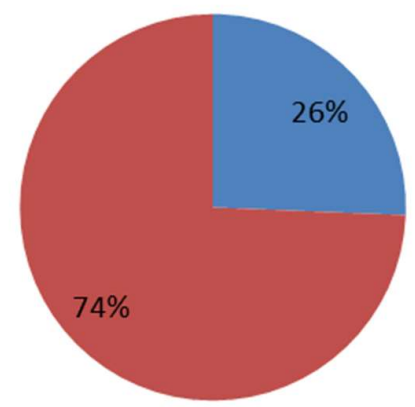

Gambar 4. Jenis Interaksi Network Co-Design of Service berdasarkan Share per postingan

interaksi sosial media pada sektor publik. Direktur media sosial di pemerintah federal Amerika Serikat menyoroti kurangnya praktik pengukuran interaksi media sosial mereka saat ini. Adanya praktik pengukuran interaksi media sosial dirasa sangat penting. Berdasarkan permasalahan tersebut, sehingga hasil dari penelitian ini adalah menghasilkan sebuah kerangka kerja pengukuran interaksi media sosial di sektor publik. Pada kerangka kerja ini menelusuri interaksi online untuk dukungan misi dan taktik media sosial yang dihasilkan. Adapun tiga jenis misi pada kerangka kerja ini adalah transparansi, partisipasi, dan kolaborasi. Sedangkan tiga taktik media sosialnya adalah one-way push, two-way pull, dan networking co-design of services [4].

Media sosial merupakan salah satu alat baru yang mempunyai potensi untuk meningkatkan interaksi antara masyarakat dengan pemerintah melalui dialog atau percakapan dan sifatnya lebih transparan. Pada penelitian ini, dilakukan pemeriksaan jaringan sosial dalam konteks alat interaktif online lain yang digunakan oleh pemerintah daerah dalam membangun interaksi dan fokus terhadap bagaimana penggunaan jaringan sosial pada studi kasus di tiga kota. Dilakukan analisis media sosial yang lebih mendalam, melalui analisis diskusi di jejaring sosial, dan wawancara terhadap studi kasusdi tiga kota yang telah menjadi pengadopsi awal penggunaan media digital, dengan menggunakan tipologi Mergel [4] yaitu, pull, push, dan networking strategies. Hasil dari eksplorasi dari ketiga kota studi kasus tersebut, menunjukkan bahwa strategi push lebih mendominasi [7].

Penggunaan media sosial mempunyai fungsi demokratis bagi pemerintah sehingga hal ini dapat meningkatkan kemampuan transparansi dan partisipasi masyarakat. Penelitian ini memperluas kerangka kerja demokrasi yang digunakan untuk menilai komunikasi pemerintah di media sosial, dengan memasukkan lingkup interaksi yang besar yang 
n Popular $\quad$ Tidak Popular

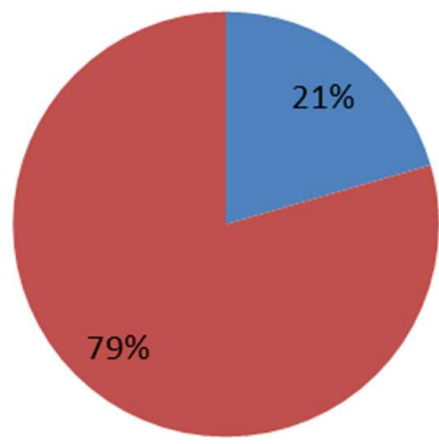

Gambar 5. Popularitas berdasarkan Followers

melibatkan pertukaran simbolis, self presentation, posisi politik dan pemasaran. Selain itu juga menilai sejauh mana pemerintah daerahmenggunakan jenis komunikasi ini melalui analisis isi pesan $\mathrm{Fa}$ cebook. Hasil dari penelitian ini menunjukkan bahwa meskipunsebagian besar konten pada halaman Facebook pemerintah daerah termasuk dalam kategori penyediaan informasi yang demokratis, namun terdapat hampir separuh dari semua pesan mengacu pada jenis pertukaran informasi yang bersifat simbolis dan presentasional. Hal ini terjadi karena media sosial bukan hanya alat untuk transparansi demokratis dan partisipasi warga, tapi juga sebagai alat untuk menunjukkan diri, pertukaran isyarat simbolis, dan pemasaran produk serta layanan [8].

Tujuan dari penelitian ini [9] adalah untuk mengukur dampak media dan jenis konten terhadap keterlibatan pemangku kepentingan pada halaman Facebook Pemerintah Eropa setempat.Sampel yang digunakan mencakup 15 negara anggota UE melalui 75 pemerintah daerah yang termasuk dalam empat gaya administrasi publik yang berbeda, dengan menganalisis 50 pos dari partisipasi masyarakat. Selanjutnya dilakukan pengkodean menjadi jenis konten dan jenis media.Hasil dari penelitian ini menunjukkan bahwa jenis media yang paling banyak digunakan adalah berupa link dan foto. Kegiatan budaya, topik olahraga dan pemasaran adalah yang paling banyak diposkan oleh pemerintah daerah Eropa Barat, namun konten ini sepertinya tidak relevan bagi masyarakat.

Penggunaan media sosial di pemerintahan menjadi salah satu tren utama dalam penelitian dan praktik Elektronik Pemerintah e-government di seluruh dunia. Media sosial memiliki potensi untuk meningkatkan inovasi pada organisasi sektor publik. Media sosial mempunyai peran di bidang dasar e-government meliputi arus informasi pemerintah dan ketersediaan informasi pemerintah, peng-
Popular $\quad$ Tidak Popular

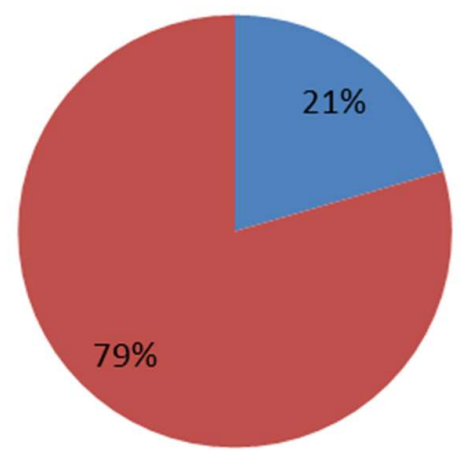

Gambar 6. Popularitas berdasarkan Like Pages

gunaan teknologi informasi untuk menciptakan dan menyediakan layanan pemerintah yang inovatif, dampak teknologi informasi terhadap hubungan antara pemerintahan dan pemerintahan, dan semakin pentingnya informasi kebijakan dan informasi teknologi untuk praktik demokrasi. Dengan demikian, penelitian ini mengusulkan dan mengembangkan tiga dimensi media sosial di pemerintahan meliputi alat, sasaran, dan topik[10].

Media sosial telah mulai digunakan oleh pemerintah sebagai alat untuk meningkatkan pelayanan publik. Pemahaman mengenai potensi media sosial untuk mencapai hasil yang diinginkan tidak sesuai dengan pemahaman tentang bagaimana dan mengapa alat spesifik digunakan untuk tujuan tertentu. Penelitian ini memanfaatkan data survei nasional yang dikumpulkan dari manajer pemerintah daerah di lima instansi yang berbeda untuk mengetahui alat media sosial yang digunakan, penggunaan alat media sosial untuk tugas atau tujuan apa, dan karakteristik organisasi yang mempengaruhi tugas dan teknologi. Hasil dari penelitian ini adalah menunjukkan bahwa manajer perlu mengembangkan strategi yang lebih jelas dalam menghubungkan alat media sosial dengan tujuan kerjanya, sebelum dapat memanfaatkan media sosial sebagai sarana komunikasi, kolaborasi dan keterlibatan pemangku kepentingan. Pada penelitian ini juga menunjukkan bahwa faktor organisasi yang berbeda mempengaruhi penggunaan media sosial untuk tujuan yang berbeda [11].

\section{Metode}

Metode yang digunakan dalam penelitian ini mengacu pada metode berdasarkan penelitian [2] untuk menganalisis dan mengkategorikan jenis interaksi antara pemerintah dan masyarakat. Penelitian ini mengambil sampel secara acak dengan 39 fanpage facebook pemerintah dari 110 kabupaten dan 
TABEL 1.

\begin{tabular}{|c|c|c|}
\hline Misi & Jenis Interaksi & $\begin{array}{l}\text { Kategori } \\
\text { Penilaian }\end{array}$ \\
\hline Transparasi & one-way push & $\begin{array}{l}\text { Followers } \\
\text { Like page }\end{array}$ \\
\hline Partisipasi & two-way pull & $\begin{array}{l}\text { Jumlah } \\
\text { postingan } \\
\text { Like postingan } \\
\text { Komentar }\end{array}$ \\
\hline Kolaborasi & $\begin{array}{l}\text { Network co-design } \\
\text { of service }\end{array}$ & $\begin{array}{l}\text { Share } \\
\text { postingan }\end{array}$ \\
\hline
\end{tabular}

kota yang mempunyai akun fanpage facebook dari jumlah 514 kabupaten dan kota. 39 fanpage facebook tersebut terdiri dari 16 kota dan 23 kabupaten yang tersebar di Indonesia. Berdasarkan teori Slovin [12], 39 sampel dari 110 populasi memiliki toleransi error sebesar 12,9\%.

39 fanpage facebook pemerintah tersebut akan diakuisisi datanya dengan mengidentifikasi jumlah pengikut (followers), suka pada pages tersebut (likepages), postingan (post), komentar (comments), postingan yang disebar (shared), dan suka pada postingan (likepost). Tujuan dari dilakukannya akuisisi data adalah untuk melihat interaksi antara pemerintah dan masyarakat melalui jumlah postingan, jumlah komentar, jumlah like dan share postingan. Sedangkan untuk melihat popularitas media sosial pemerintah, dilakukan akusisi data pengikut dan likes fanpage facebook. Proses akuisisi data dilakukan selama 40 hari.

Langkah pertama yang dilakukan adalah memberikan inisial pada masing-masing kota dan kabupaten untuk memudahkan dalam menampilkan hasil dari proses akuisisi data. Lalu mengidentifikasi jumlah postingan, komentar, like dan share pada ke-39 fanpage facebook pemerintah. Langkah selanjutnya, dari hasil identifikasi tersebut dilakukan analisa deskriptif dengan menentukan nilai rata-rata. Metode yang digunakan untuk melakukan kategorisasi jenis interaksi dan penentuan popularitas didasarkan pada kerangka kerja yang dikembangkan oleh [4], yang mana ditentukan 3 jenis interaksi berdasarkan misi pembuatan media sosial pemerintah. Jenis interaksi tersebut adalah one-way push, two-way pull, dan networking codesign of service, yang mana jenis interaksi ini memiliki masing-masing kategori penilaian di dalamnya. Tabel 1 menampilkan kategorisasi jenis interaksi media sosial beserta misi dan kategori penilaiannya.

Hasil akuisisi data postingan, like, komentar, followers dan share selama 40 hari dari masingmasing indikator penilaian (followers, like page, jumlah postingan per hari, like per postingan, komentar per postingan dan share per postingan) dijumlahkan lalu dihitung rata-rata dari masing-masing kategori penilaian tersebut. Setelah didapatkan hasil perhitungan rata-rata, dilakukan analisis deskriptif dalam interaksi one-way push, two-way pull, dan networking co-design of service sesuai dengan kategori penilaian. Jika nilai kategori penilaian lebih besar dari rata-rata kategori penilaian, maka dinyatakan interaksi yang dilakukan intensif atau populer.

\section{Hasil dan Analisis}

Berdasarkan akusisi data yang telah dilakukan pada 39 fanpage facebook pemerintah daerah selama rentang waktu 2 bulan dan 10 hari, maka berikut ini adalah hasil yang diperoleh dari analisis kategorisasi menurut jenis interaksi dan tingkat popularitas pada media sosial fanpage facebook pemerintah.

\section{Kategorisasi Jenis Interaksi}

Gambar 1 menunjukkan hasil dari pengkategorisasian berdasarkan jenis interaksi. Tabel 2 menjelaskan hasil dari identifikasi interaksi yang dilakukan oleh pememerintah daerah secara umum berdasarkan pada penelitian [4]. Secara keseluruhan dari tiga aspek (postingan, komentar, dan likes), didapatkan bahwa postingan, komentar dan likes dari fanpage pemerintah daerah masih tergolong rendah karena berada di bawah nilai rata-rata. Untuk mengetahui optimasi dari masing-masing jenis interaksi, akan dijelaskan pada masing-masing sub subbab berikut ini.

\section{Jenis Interaksi One Way Push}

Berdasarkan hasil akuisisi data yang dilakukan, ke39 fanpage facebook pemerintah daerah telah melakukan jenis interaksi one way push. Hal ini terlihat dari teadanya followers dan like page pada fan-page facebook masing-masing pemerintah daerah.

\section{Jenis Interaksi Two Way Pull}

Pengukuran jenis interaksi two way pull dilakukan dengan membandingkan rata-rata postingan per hari pemerintah daerah dengan rata-rata postingan per hari semua pemerintah daerah. Berdasarkan hasil akuisisi data yang dilakukan pada ke-39 fanpage 
TABEL 2.

KATEGORISASI JENIS INTERAKSI

\begin{tabular}{cccc}
\hline $\begin{array}{c}\text { Kategori } \\
\text { Penilaian }\end{array}$ & $\begin{array}{c}\text { Rata- } \\
\text { rata post } \\
\text { per hari }\end{array}$ & $\begin{array}{c}\text { Jumlah di } \\
\text { atas rata-rata }\end{array}$ & $\begin{array}{c}\text { Jumlah di } \\
\text { bawah rata- } \\
\text { rata }\end{array}$ \\
\hline Postingan & 1.73 & $43.59 \%$ & $56.41 \%$ \\
Komentar & 1.11 & $35.90 \%$ & $64.10 \%$ \\
Likes & 26.93 & $25.64 \%$ & $74.36 \%$ \\
\hline
\end{tabular}

facebook pemerintah daerah, hasil yang didapat menyatakan bahwa terdapat $95 \%$ fanpage facebook pemerintah daerah telah melakukan jenis interaksi two way pull berdasarkan postingan per hari. Melalui semua data tersebut pada Gambar 1, didapatkan sebanyak $44 \%$ fanpage facebook pemerintah daerah yang telah melakukan postingan secara intensif. Sebanyak $56 \%$ masih belum intensif dalam melakukan postingan per hari.

Selain itu pengukuran jenis interaksi two way pull juga dilakukan dengan membandingkan ratarata komentar per post pememerintah daerah dengan rata-rata komentar per post semua pemerintah daerah. Hasil yang didapat menyatakan bahwa terdapat $95 \%$ fanpage facebook pemerintah daerah telah melakukan jenis interaksi two way pull berdasarkan komentar per post. Melalui semua data tersebut, didapat sebanyak 36\% fanpage facebook pemerintah daerah yang telah dikomentari secara intensif, sementara $64 \%$ masih belum intensif. Hal ini seperti terlihat pada Gambar 2.

Pengukuran jenis interaksi two way pull pada like, dilakukan dengan membandingkan rata-rata like per postingan pemerintah daerah dengan ratarata like per postingan semua pemerintah daerah. Hasil yang didapatkan juga menyatakan bahwa terdapat 95\% fanpage facebook pemerintah daerah telah melakukan jenis interaksi two way pull berdasarkan like per postingan. Melalui semua data tersebut, didapatkan sebanyak 26\% fanpage facebook pemerintah daerah yang telah di-like secara intensif. Sebanyak $74 \%$ masih belum di-like secara intensif. Hal ini seperti terlihat pada Gambar 3.

\section{Jenis Interaksi Network Co-Design of Service}

Pengukuran jenis interaksi network co-design of service dilakukan dengan membandingkan ratarata share per postingan pemerintah daerah dengan rata-rata share per postingan semua pemerintah daerah. Berdasarkan hasil akuisisi data, hasil yang didapat menyatakan bahwa terdapat 95\% fanpage facebook pemerintah daerah telah melakukan jenis interaksi network co-design of service berdasarkan share per postingan. Melalui semua data tersebut, didapatkan sebanyak 26\% fanpage facebook pemerintah daerah yang melakukan share per postingan secara intensif. Sebanyak 74\% masih belum intensif. Gambar 4 menunjukkan persentase ini.
TABEL 3

TINGKATAN POPULARITAS

\begin{tabular}{ccc}
\hline No & Tingkatan & Persentase Pemerintah daerah \\
\hline 1 & Populer & $21 \%$ \\
2 & Tidak Populer & $79 \%$ \\
\hline
\end{tabular}

\section{Popularitas Fanpages}

Pengukuran popularitas fanpages dilakukan dengan membandingkan rata-rata followers dan likes page masing-masing pemerintah daerah dengan rata-rata followers dan likes page semua pemerintah daerah. Tingkat popularitas dari 39 fanpage facebook pemerintah daerah dapat dilihat pada Tabel 3. Penggolongan dilakukan berdasarkan data akuisisi (jumlah followers dan like fanpage).

Secara keseluruhan dari dua aspek (jumlah followers dan like fanpage), didapatkan bahwa dari hasil analisis akuisisi data, fanpage pemerintah daerah masih tergolong tidak populer sebanyak $79 \%$ dan tingkat populer sebanyak $21 \%$. Diagram pada Gambar 5 menjelaskan lebih detail mengenai tingkat popularitas berdasarkan jumlah follower. Sedangkan untuk popularitas berdasarkan jumlah like fanpage facebook pemerintah daerah, $21 \%$ di antaranya termasuk dalam kategori popular dan $79 \%$ termasuk dalam kategori tidak popular. Untuk pemetaannya dapat dilihat pada Gambar 6. Berdasarkan hasil tersebut, tingkat popularitas masih sedikit, hal ini berdampak pada misi pemerintah dalam menggunakan media sosial sebagai salah satu media komunikasi dengan masyarakat.

\section{Interaksi Masyarakat dan Pemerintah}

Bentuk interaksi yang terjadi antara masyarakat dengan pemerintah dapat dilihat dari data jumlah like post dan komentar pada laman facebook milik pemerintah. Hasil dari analisis data dari penggunaan media sosial facebook oleh pemerintah daerah, berdasarkan jumlah like post, didapatkan sejumlah 26 $\%$ facebook pemerintah daerah sudah intensif. Namun, 74\% facebook pemerintah daerah belum intensif. Sedangkan jumlah komentar pada posting pemerintah menunjukkan 36\% facebook pemerintah daerah sudah intensif, sementara 64\% facebook pemerintah daerah belum intensif. Berdasarkan hasil ini, dapat dilihat bahwa sebagian besar penggunaan media sosial oleh pemerintah daerah di Indonesia belum secara maksimal dapat mendorong terjadinya interaksi antara masyarakat dan pemerintah. Hal ini juga didukung dari penelitian sebelumnya bahwa keberhasilan komunikasi melalui penggunaan media sosial yang dilakukan oleh pemerintah dapat dilihat dari jumlah komentar masyarakat terhadap postingan pemerintah [2].

Adanya jumlah like post menunjukkan bahwa adanya respon masyarakat terhadap posting dari 
pemerintah. Sedangkan adanya komentar pada posting dari pemerintah menunjukkan bahwa adanya feedback dari masyarakat. Salah satu tujuan dari penggunaan media sosial bagi pemerintah adalah untuk mendapatkan respon dan feedback dari masyarakat sehingga dapat mendorong terjadinya interaksi antara masyarakat dengan pemerintah. Hal ini sesuai dengan penelitian sebelumnya bahwa media sosial dapat mempermudah mendapatkan feedback dan respon dari masyarakat [6].

\section{Popularitas Fanpage Pemerintah}

Berdasarkan hasil yang diperoleh dari akuisisi data fanpage facebook pemerintah didapatkan sebanyak $21 \%$ termasuk dalam kategori populer sedangkan sisanya sebanyak $79 \%$ termasuk dalam kategori tidak populer. Penggolongan ini berdasarkan jumlah followers dan jumlah like fanpages. Sesuai dengan penelitian yang dilakukan oleh [4] bahwa salah satu tujuan pemerintah di United State (US) untuk menggunakan media sosial adalah untuk transparansi. Transparansi tersebut dilihat berdasarkan jumlah followers dan like fanpages. Tujuan ini nantinya akan diharapkan menghasilkan kepercayaan dari masyarakat. Tentunya, dengan menggunakan media sosial untuk tujuan transparasi tersebut dilihat seberapa banyaknya masyarakat mengenal dan mengetahui informasi yang disebarkan melalui fanpage pemerintah tersebut. Ukuran seberapa banyak tersebut berkaitan dengan jumlah pengikut dan jumlah masyarakat yang menyukai fanpages tersebut.

Pada penelitian sebelumnya menyatakan hal yang sama bahwa media sosial pada pemerintah dapat meningkatkan kepuasan dan kepercayaan warga [13]. Tingkat tinggi penggunaan media sosial cenderung memungkinkan warga untuk mengawasi pemerintahan dan membuat informasi,data dan proses lebih transparan [14]. Temuan mengungkapkan pola aplikasi media sosial untuk tujuan tertentu, meskipun organisasi tidak semua menggunakan alat media sosial dengan cara yang sama. Media sosial sebagai media komunikasi, media sosial untuk umpan balik pada kualitas layanan, media sosial untuk partisipasi dan media sosial untuk kolaborasi kerja internal [11].

Namun, penelitian lain mengatakan bahwa adopsi media sosial oleh pemerintah dapat menyebabkan beberapa kerugian, seperti kehilangan kontrol karena transparansi yang berlebihan, rendahnya tingkat partisipasi atau perilaku destruktif oleh pengguna, adanya masalah privasi dan keamanan [15], atau kurangnya budaya yang ada pada warga negara dan risiko yang terkait dengan gaya komunikasi [13]. Dalam hal ini, perlu adanya strategi implementasi yang baik oleh pemerintah diperlukan untuk mendapatkan keuntungan dari media sosial. Dengan strategi yang baik tentunya dapat meningkatkan popularitas media sosial yang digunakan oleh pemerintah daerah.

\section{Kesimpulan}

Penggunaan aplikasi media sosial sudah mulai merambah pada kepemerintahan di Indonesia. Aplikasi media sosial merupakan salah satu alternatif media komunikasi antara pemerintah dan masyarakat. Media sosial pemerintah daerah dapat diakses secara luas dan penggunanya dapat saling berinteraksi termasuk masyarakat dan pemerintahan. Penggunaan media sosial dapat menyediakan interaksi dua arah antara masyarakat sebagai pengelola informasi yang disebarkan dan mampu berinteraksi atau menjawab feedback yang diberikan oleh masyarakat.

Dari interaksi antara masyarakat dengan pemerintah perlu dilakukan kategorisasi jenis interaksi. Penggolongan jenis interaksi dibagi menjadi tiga tipe taktikal interaksi berdasarkan misi dan tujuan dari pembuatan media sosial bagi pemerintah, yaitu,misi tranparansi, misi partisipasi, dan misi kolaborasi. Berdasarkan misi dan tujuan dari pembuatan media sosial bagi pemerintah, saat ini pemerintah melakukan interaksi one way push, two way pull dan network co-design of service.

Berdasarkan hasil akuisisi data yang dilakukan pada 39 pemerintah daerah di Indonesia menunjukkan bahwa $100 \%$ fanpage facebook pemerintah daerah telah melakukan jenis interaksi one way push. Sejumlah 95\% fanpage facebook pemerintah daerah telah melakukan jenis interaksi two way pull berdasarkan postingan per hari. Sejumlah 95\% fanpage facebook pemerintah daerah telah melakukan jenis interaksi network co-design of service berdasarkan share per postingan.

Berdasarkan hasil yang diperoleh dari akuisisi data fanpage facebook pemerintah didapatkan sebanyak $21 \%$ termasuk dalam kategori populer sedangkan sisanya sebanyak $79 \%$ termasuk dalam kategori tidak populer. Penggolongan ini berdasarkan jumlah followers dan jumlah like fanpages. Hasil dari penelitian ini menunjukkan bahwa tingkat popularitas fanpage facebook pemerintah daerah di Indonesia tergolong rendah. Hal ini juga berkaitan dengan jenis interaksi yang terjadi, dibuktikan dengan masih rendahnya partisipasi dan kolaborasi antara masyarakat dengan pemerintah yang dilihat dari jumlah like post dan jumlah komentar pada facebook yang sebagian besar tidak insentif.

Penelitian selanjutnya dapat mempertimbangkan untuk membahas strategi implementasi yang 
baik oleh pemerintah diperlukan untuk mendapatkan keuntungan dari media sosial. Dengan strategi yang baik tentunya dapat meningkatkan popularitas media sosial yang digunakan oleh pemerintah daerah. Selanjutnya, penelitian dapat mengkategorisasikan jenis interaksi lainnya selain tiga jenis interaksi yang dibahas pada penelitian ini.

\section{Referensi}

[1] F. C. Lunenburg, "Communication : The Process, Barriers, And Improving Effectiveness," Schooling, vol. 1, pp. 1-11, 2010.

[2] S. Hofmann, D. Beverungen, M. Räckers, and J. Becker, "What makes local governments" online communications successful? Insights from a multi-method analysis of Facebook," Gov. Inf. Q., vol. 30, no. 4, pp. 387-396, 2013.

[3] M. Vos and E. Westerhoudt, "Trends in government communication in The Netherla-nds," J. Commun. Manag., vol. 12, no. 1, pp. 1829, 2008.

[4] I. Mergel, "A framework for interpreting social media interactions in the public sector," Gov. Inf. Q., vol. 30, no. 4, pp. 327-334, 2013.

[5] R. Medaglia and D. Zhu, "Public deliberation on government-managed social media: A study on Weibo users in China," Gov. Inf. Q., no. May, pp. 0-1, 2017.

[6] M. Guillamón, A. Ríos, B. Gesuele, and C. Metallo, "Factors in fl uencing social media use in local governments: The case of Italy and Spain," Gov. Inf. Q., 2016.

[7] K. Mossberger, Y. Wu, and J. Crawford, "Connecting citizens and local governments? Social media and interactivity in major U.S. cities," Gov. Inf. Q., vol. 30, no. 4, pp. 351-358,
2013.

[8] N. DePaula, E. Dincelli, and T. M. Harrison, "Toward a typology of government social media communication: Democratic goals, symbolic acts and self-presentation," Gov. Inf. Q., no. October 2016, pp. 1-10, 2017.

[9] E. Bonsón, S. Royo, and M. Ratkai, "Citizens $\hat{a} €^{\mathrm{TM}}$ engagement on local governments $\hat{a} €^{\mathrm{TM}}$ Facebook sites. An empirical analysis: The impact of different media and content types in Western Europe," Gov. Inf. Q., 2014.

[10] J. I. Criado, R. Sandoval-Almazan, and J. R. Gil-Garcia, "Government innovation through social media," Gov. Inf. Q., vol. 30, no. 4, pp. 319-326, 2013.

[11] G. H. M. Oliveira and E. W. Welch, "Social media use in local government: Linkage of technology, task, and organizational context," Gov. Inf. Q., vol. 30, no. 4, pp. 397-405, 2013.

[12] Sugiyono, Metode Penelitian Pendidikan Pendekatan Kuantitatif, Kualitatif, dan $R \& D$. Bandung: Alfabeta, 2014.

[13] S. Picazo-Vela, I. Gutiérrez-Martínez, and L. F. Luna-Reyes, "Understanding risks, benefits, and strategic alternatives of social media applications in the public sector," Gov. Inf. Q., vol. 29, no. 4, pp. 504-511, 2012.

[14] M. R. Vicente and A. Novo, "An empirical analysis of e-participation. The role of social networks and e-government over citizens' online engagement," Gov. Inf. Q., vol. 31, no. 3, pp. 379-387, 2014.

[15] J. C. Bertot, P. T. Jaeger, and J. M. Grimes, "Using ICTs to create a culture of transparency: E-government and social media as openness and anti-corruption tools for societies," Gov. Inf. Q., vol. 27, no. 3, pp. 264-271, 2010. 